\title{
Razvoj suradnje probacijskog i zatvorskog sustava - idemo li u dobrom smjeru?
}

\author{
Snježana Maloić \\ Ministarstvo pravosuđa \\ Uprava za zatvorski sustav i probaciju \\ Sektor za probaciju \\ E-mail: snjezana.maloic@pravosudje.hr \\ Goran Brkić \\ Ministarstvo pravosuđa \\ Uprava za zatvorski sustav i probaciju \\ Sektor za probaciju
}

\begin{abstract}
Sažetak
Hrvatska je probacijska služba započela s radom 2011. godine, a probacijske poslove tijekom izvršavanja kazne zatvora i uvjetnog otpusta obavlja od 2013. godine. Od tada broj ovih predmeta kontinuirano raste te se sada polovica svih predmeta koje godišnje zaprima probacijska služba odnosi na izvršavanje ovih probacijskih poslova. Veći broj predmeta i veća uključenost probacijske službe tijekom izvršavanja kazne zatvora i uvjetnog otpusta ukazuje i na potrebu kvalitetne suradnje probacijskog i zatvorskog sustava. Na europskom se području učinkovita suradnja zatvorskih i probacijskih sustava smatra nužnom za svrhovito izvršavanje kazni zatvora i obavljanje probacijskih poslova. U okviru rehabilitacijskog pristupa prepoznate su određene manjkavosti postojećih suradnji, uz istovremeno isticanje modaliteta koji se pokazuju učinkovitima ili obećavajućima. Ovaj rad donosi analizu razvoja suradnje probacijskog i zatvorskog sustava u našoj zemlji, u odnosu na postojeća europska iskustva, uz zaključne preporuke daljnjeg razvoja te suradnje u smjeru dobrih europskih praksi.
\end{abstract}

Ključne riječi: probacija, probacijski poslovi, zatvor, zatvorska kazna, uvjetni otpust

\section{Uvod}

U početku rada hrvatska probacijska služba obavljala je samo poslove rada za opće dobro i uvjetne osude sa zaštitnim nadzorom čije je izricanje ponajprije bilo namijenjeno počiniteljima lakših kaznenih djela. Danas je uključena u sve faze (pred)kaznenog postupka i provedbe kaznenopravnih sankcija pa je tako obavljanjem probacijskih poslova sve aktivnije uključena i tijekom izvršavanja kazne zatvora i uvjetnog otpusta. Aktualno se polovica ukupno zaprimljenih predmeta službe odnosi na obavljanje ovih poslova (Ministarstvo pravosuđa, 2018a). Da bi se ti poslovi mogli kvalitetno obavljati, potrebna je dobra suradnja probacijskog i zatvorskog sustava. Probacijska služba u našoj zemlji postoji tek posljednjih desetak godina i u procesu je osmišljavanja i razvoja suradnje s različitim institucijama i organizacijama pa tako i sa zatvorskim sustavom. 
Svrha je ovog rada analizirati razvoj suradnje probacijskog i zatvorskog sustava u našoj zemlji u odnosu na postojeća europska iskustva, uz zaključne preporuke daljnjeg razvoja te suradnje u smjeru dobrih europskih praksi.

U domaćoj je literaturi već opisana inicijalna suradnja probacijske službe sa zatvorskim sustavom, koja je bila uspostavljena neposredno nakon osnivanja službe (Maloić, Rajić i Mažar, 2015), te se stoga u ovom radu neće ponovno prikazivati.

\section{Ustrojavanje probacijske službe u Republici Hrvatskoj}

Inicijativa ustrojavanja probacijske službe u našoj zemlji nastala je u okviru zatvorskog sustava. Tako je i prvi Odjel za izvršavanje uvjetne osude sa zaštitnim nadzorom i radom za opće dobro na slobodi bio osnovan u okviru Središnjeg ureda Uprave za zatvorski sustav. Visoka motivacija zatvorskog sustava za ustrojavanjem ove službe u prvom redu proizlazila je iz tada velike prekapacitiranosti zatvorskog sustava. Radom službe, uz naknadne zakonske izmjene kojima je omogućeno izricanje većeg broja probacijskih mjera i sankcija, značajno se smanjila zatvorska populacija. Time je nestao i niz problema zatvorskog sustava povezanih s izrazitom prekapacitiranošću na koje se godinama ukazivalo (Mihoci, 2006; Kovčo Vukadin, Lotar, Barić, 2012). Dok je 2011. godine u zatvorskom sustavu bilo 5084 zatvorenika, 2016. godine bilo ih je 3079, što svakako predstavlja velik pad broja zatvorenika (39,4\%) (Ministarstvo pravosuđa, 2017).

Probacijski se sustav od zatvorskog odvojio i počeo ustrojavati kao samostalan 2009. godine, kada je unutar Ministarstva pravosuđa osnovana Uprava za probaciju, da bi se kasnije nastavio razvijati i u okviru drugih uprava, s obzirom na promjene u ustrojstvu Ministarstva pravosuđa. Te je godine desetak službenika iz Središnjeg ureda Uprave za zatvorski sustav premješteno u novoosnovanu Upravu za probaciju sa zadaćama pronalaženja prostora za probacijske urede, opremanja ureda, zapošljavanja službenika i osmišljavanja protokola obavljanja probacijskih poslova. Prvi su uredi počeli s radom 2011. godine, a potom su otvarani tijekom 2011. i 2012. godine do početka 2013. godine. Dva zadnja ureda otvorena su u Gospiću i Vukovaru 2018. godine, tako da je do sada otvoreno ukupno četrnaest probacijskih ureda - Slika 1.

Slika 1. Probacijski uredi u Republici Hrvatskoj (Ministarstvo pravosuđa, 2018a).

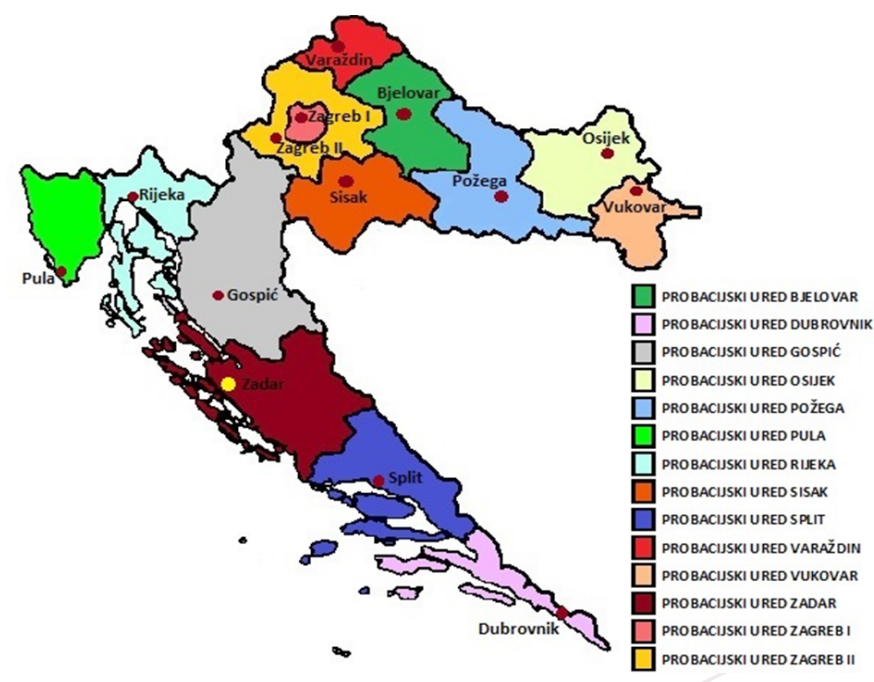


Snježana Maloić, Goran Brkić: Razvoj suradnje probacijskog i zatvorskog sustava...

Razvoju službe značajno su pridonijela sredstva iz europskih fondova, kojima su namješteni i informatički opremljeni probacijski uredi, osmišljen je probacijski informacijski sustav, kupljeni su automobili, educirani su probacijski službenici, a realizirano je i više studijskih posjeta probacijskim sustavima europskih država (Kovčo Vukadin, Rajić i Maloić, 2011; Kovčo Vukadin i Špero, 2015; Špero i Rosandić, 2017). Od 2010. godine služba se razvijala u okviru Uprave za probaciju i podršku žrtvama i svjedocima, a potom od 2012. godine u okviru Uprave za kazneno pravo i probaciju, sve unutar Ministarstva pravosuđa.

Od 2017. godine zatvorski i probacijski sustav i nadalje funkcioniraju unutar istog Ministarstva, sada i u okviru iste uprave pod nazivom Uprava za zatvorski sustav i probaciju, kao Sektor za zatvorski sustav i Sektor za probaciju. Strateški je razvoj Uprave, kao i za sve druge uprave, planiran u okviru Strateškog plana Ministarstva pravosuđa za razdoblje od 2019. do 2021. godine (Ministarstvo pravosuđa, 2018b). Uvidom u ovaj dokument vidljivo je da je razvoj svakog sustava donekle planiran zasebno, s nešto manjim naglaskom na budućim zajedničkim aktivnostima. Ipak, funkcioniranje ovih dvaju sustava u okviru iste Uprave otvara niz novih mogućnosti međusobne suradnje, o čemu će biti više riječi u nastavku rada.

\section{Probacijski poslovi tijekom izvršavanja kazne zatvora i uvjetnog otpusta}

Hrvatski zatvorski sustav, u suradnji s domaćom znanstvenom zajednicom, tradicionalna je usmjerenja prema rehabilitaciji počinitelja kaznenih djela i njihovoj socijalnoj reintegraciji. Ovaj je pristup ostao dominantnim i u vrijeme svojevrsne "krize" rehabilitacijskog pristupa, a na važnost učinkovite primjene ovog pristupa naglašavalo se i ukazivanjem na moguća poboljšanja u domaćoj penološkoj praksi (Bašić i Žižak, 1990; Žakman-Ban, 1992; Kovčo 1997; Mejovšek, 1998; Mikšaj-Todorović i Buđanovac, 2000; Kovčo, 2001; Buđanovac i Mikšaj-Todorović, 2002; Damjanović, Jandrić i Doležal, 2002; Jandrić, 2006; Uzelac, Žakman-Ban i Farkaš, 2008). Ne čudi stoga da je i probacijska služba, koja je i nastajala u okviru zatvorskog sustava, prihvatila i razvija rehabilitacijski pristup.

Člankom 2. Zakona o izvršavanju zatvorske kazne (Narodne novine, 128/99, 55/00, 59/00, 129/00, 59/01, 67/01, 11/02, 190/03, 76/07, 27/08, 83/09, 18/11, 48/11,125/11, 56/13, 150/13) navodi se glavna svrha kažnjavanja jest, uz čovječno postupanje i poštivanje dostojanstva osobe koja se nalazi na izdržavanju kazne zatvora ..., njegovo osposobljavanje za život na slobodi u skladu sa zakonom i društvenim pravilima. Člankom 2. Zakona o probaciji (Narodne novine, 99/18) propisano je da se probacijski poslovi obavljaju radi zaštite društvene zajednice od počinitelja kaznenog djela, njegove resocijalizacije i reintegracije u zajednicu utjecanjem na rizične čimbenike koji su povezani s činjenjem kaznenih djela. Vidljivo je da su oba sustava usmjerena na rad s počiniteljem kaznenog djela u smjeru prevencije recidiva u činjenju kaznenog djela i na reintegraciju počinitelja u zajednicu, što svakako otvara prostor za suradnju.

Već od samog početka osmišljavanja probacijskih poslova u našoj zemlji, razmišljalo se u smjeru potrebe pa i nužnosti zajedničkog rada ovih dvaju sustava (Petö Kujundžić i Vukota, 2009; Šimpraga i Vukota 2010; Maloić i sur., 2015).

Prvim Zakonom o probaciji (Narodne novine, 153/09) bio je 2009. godine propisan cijeli niz probacijskih poslova povezanih s izvršavanjem kazne zatvora, uvjetnim otpustom i poslijepenalnom 
zaštitom. Međutim, snažna gospodarska kriza u zemlji i svijetu usporavala je razvoj službe, a time je bio odgođen i početak provođenja većine poslova. Poslovi vezani uz prihvat zatvorenika nakon otpusta od 2013. godine Zakonom o probaciji (Narodne novine, 143/12) više nisu bili propisani kao probacijski poslovi, a nisu ponovno propisani ni aktualnim Zakonom o probaciji. Od početka 2013. godine probacijska je služba postupno započinjala s obavljanjem svih ostalih probacijskih poslova tijekom izvršavanja kazne zatvora i uvjetnog otpusta, koje obavlja i danas, a propisani su Zakonom o probaciji donesenim 2018. godine (Narodne novine, 99/18). Uz kontinuirani porast broja ovih, ali i drugih predmeta, služba danas obavlja poslove tijekom svih faza kaznenog postupka i izvršavanja kaznenopravnih sankcija - Shematski prikaz 1.

\section{Shematski prikaz 1. Probacijski poslovi koje obavlja hrvatska probacijska služba (Ministarstvo pravosuđa, 2018a - korigirano s obzirom na donošenje novog Zakona o probaciji, Narodne novine, 99/18)}

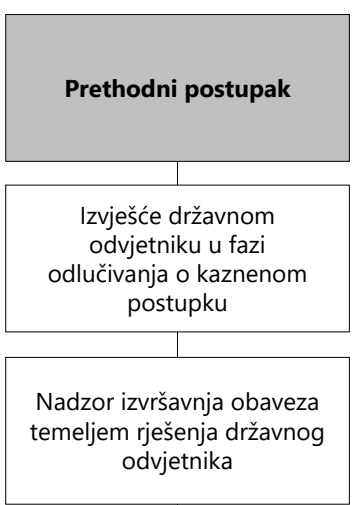

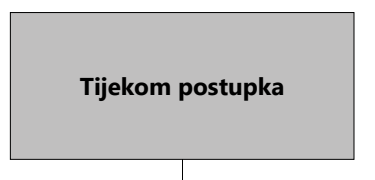
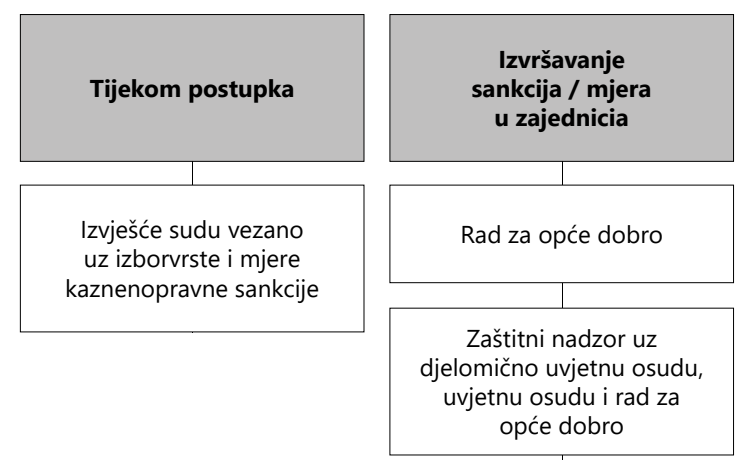

Nadzor izvršavanja posebnih obaveza (čl. 62. KZ-a)

Nadzor izvršavanja

sigurnosnih mjera

(čl. 68., 69. i 70. KZ-a)

Iz shematskog prikaza 1 vidljivo je da služba obavlja cijeli niz poslova vezanih uz izvršavanje kazne zatvora, uvjetnog otpusta i djelomične uvjetne osude. Zaštitni nadzor uz djelomičnu uvjetnu osudu ponajprije se smatra sankcijom koja se provodi u zajednici, što je točno, no uvijek se provodi nakon izvršene kazne zatvora te je stoga i ova sankcija istaknuta u okviru prikaza.

Probacijski službenici rade s osuđenikom tijekom uvjetnog otpusta ako je uz uvjetni otpust izrečen zaštitni nadzor ili neka od posebnih obveza iz čl. 62. Kaznenog zakona (Narodne novine, 125/11, 144/12, 56/15 61/15, 101/17) za čije je provođenje služba nadležna. Kada službenici Odjela tretmana zatvora, odnosno kaznionice, planiraju uz uvjetni otpust predložiti i zaštitni nadzor ili posebne obveze zatvorenika već tijekom izdržavanja zatvorske kazne, to jest tijekom korištenja pogodnosti izlaska u mjesto prebivališta / planiranog otpusta, upućuju se u nadležni probacijski ured. Na taj se način prvi kontakt zatvorenika i probacijskog službenika ostvaruje još tijekom izdržavanja zatvorske kazne. Kod izricanja djelomične uvjetne osude, sud unaprijed određuje koliki će se dio izrečene kazne provesti u okviru zatvorskog sustava, a koliki dio na uvjetovanoj slobodi. Na uvjetovanoj slobodi s osuđenikom radi probacijska služba ako je izrečen zaštitni nadzor i/ili su izrečene sigurnosne 
Snježana Maloić, Goran Brkić: Razvoj suradnje probacijskog i zatvorskog sustava...

mjere ili posebne obveze koje nadzire služba. Dakle, kao i kod uvjetnog otpusta, rad probacijskih službenika s osuđenikom izravno se nastavlja na rad zatvorskih službenika s istim osuđenikom.

Uz te poslove, koji podrazumijevaju tretmanski rad probacijskog službenika s počiniteljem kaznenog djela, od velika su značaja i poslovi službe koji se odnose na izradu izvješća kaznionici, odnosno zatvoru ili sudcu izvršenja. Kod ovih poslova radom u zajednici prikupljaju se i dostavljaju podatci prijeko potrebni za donošenje odluka o daljnjem tijeku rada sa zatvorenikom. Na zahtjev zatvora, odnosno kaznionice, dostavlja se izvješće pri odlučivanju o korištenju pogodnosti izlaska zatvorenika. Kada odlučuje o prekidu zatvorske kazne, sudac izvršenja u pravilu traži izvješće službe, a služba i radi s osuđenikom tijekom prekida ako sudac izvršenja naloži javljanje osuđenika u probacijski ured. Na zahtjev sudca izvršenja, odnosno na zahtjev predsjednika Vijeća za uvjetni otpust, dostavlja se i izvješće pri odlučivanju o uvjetnom otpustu.

Od ukupno 4124 zaprimljena predmeta koliko ih je 2017. godine zaprimila služba, 2149 predmeta odnosilo se na obavljanje probacijskih poslova tijekom izvršavanja zatvorske kazne, uvjetnog otpusta i djelomične uvjetne osude, to jest 52,2 \% zaprimljenih predmeta - prikazano tablicom 1.

Tablica 1. Zaprimljeni i završeni predmeti probacijske službe tijekom 2017. godine (Ministarstvo pravosuđa, 2018a)

\begin{tabular}{|l|c|c|}
\hline VRSTA PREDMETA 2017. & $\begin{array}{c}\text { Broj } \\
\text { zaprimljenih } \\
\text { predmeta }\end{array}$ & $\begin{array}{c}\text { Broj } \\
\text { završenih } \\
\text { predmeta }\end{array}$ \\
\hline Uvjetni otpust & 208 & 322 \\
\hline Uvjetni otpust uz posebne obveze & 452 & 453 \\
\hline Uvjetni otpust uz elektronički nadzor & 4 & 4 \\
\hline Zaštitni nadzor nakon punog izvršenja kazne zatvora & 1 & 0 \\
\hline Nadzor prekida izvršavanja kazne zatvora & 25 & 22 \\
\hline Javljanje zatvorenika u probacijski ured tijekom pogodnosti izlaska & 65 & 69 \\
\hline Djelomična uvjetna osuda sa zaštitnim nadzorom / sigurnosnom mjerom / posebnom obvezom & 28 & 6 \\
\hline Izvješća za kaznionicu/zatvor & 137 & 132 \\
\hline Izvješća za sudca izvršenja & 1230 & 1175 \\
\hline Uvjetna osuda sa zaštitnim nadzorom / sigurnosnom mjerom / posebnom obvezom & 495 & 175 \\
\hline Izvješća za državnog odvjetnika & 6 & 6 \\
\hline Izvršavanje obveza koje je naložio državni odvjetnik & 78 & 65 \\
\hline Izvješća za sud pri odlučivanju o sankciji & 23 & 21 \\
\hline Istražni zatvor u domu uz elektronički nadzor & 1 & 1 \\
\hline UKUPNO & $\mathbf{4 1 2 1}$ & $\mathbf{3 7 6 9}$ \\
\hline
\end{tabular}

Budući da je tijekom 2012. godine služba zaprimila manje od 100, a izvršila manje od 10 ovih predmeta (Ministarstvo pravosuđa, 2014), broj zaprimljenih i izvršenih predmeta u 2017. godini svakako predstavlja velik pomak. Pri tome treba napomenuti da uvjetni otpust uz elektronički nadzor i istražni zatvor uz elektronički nadzor (navedeni u okviru tabličnog prikaza 1) nisu probacijski poslovi koje uobičajeno izvršava služba, već su ovi predmeti rezultat provođenja pilot-projekta Inicijalna primjena elektroničkog nadzora u Republici Hrvatskoj, o kojem će biti više riječi u nastavku rada. Također, potrebno je napomenuti da služba do sada nije izvršavala nijednu presudu u kojoj bi bio izrečen zaštitni nadzor nakon punog isteka zatvorske kazne, a koju bi donio domaći sud. Jedini takav predmet, koji se navodi u tabličnom prikazu 1, izrekao je austrijski sud dok domaći sud samo nadzire izvršavanje. 
Autori ovog rada zapitali su se, prati li povećanje broja predmeta i opsega probacijskih poslova tijekom izvršavanja kazne zatvora, uvjetnog otpusta i djelomične uvjetne osude i adekvatna suradnja probacijskog i zatvorskog sustava te razvija li se ta suradnja u smjeru dobrih europskih praksi. Pritom je potrebno imati u vidu i da ova dva sustava dijelom rade $s$ istim počiniteljima kaznenih djela bilo da su im prije izdržavanja kazne zatvora bile izrečene probacijske mjere i sankcije bilo da su tijekom izvršavanja kazne zatvora uključeni u obavljanje probacijskih poslova ili se u obavljanje ovih poslova uključuju u okviru uvjetnog otpusta ili djelomične uvjetne osude. Određenom broju počinitelja kaznenih djela, koji su već bili na izvršavanju kazne zatvora, zbog počinjenoga novog kaznenog djela nakon otpusta ponovno budu izrečene probacijske mjere, odnosno sankcije. Također, dijelu osuđenika uključenih u obavljanje probacijskih poslova, zbog nepridržavanja obveza iz pojedinačnog programa, ili iz drugih razloga (na primjer, novo kazneno djelo), opoziva se uvjetna osuda ili im se rad za opće dobro zamijeni zatvorskom kaznom. Sve navedeno autorima ovog rada bio je i dodatni poticaj za analizu suradnje probacijskog i zatvorskog sustava u našoj zemlji u odnosu na europska iskustva. $\mathrm{U}$ tu svrhu kratko će se u nastavku rada prikazati i neka europska iskustva i modaliteti suradnje ovih dvaju sustava.

\section{Suradnja probacijskih i zatvorskih sustava u Europi}

Proces prestanka činjenja kaznenih djela (engl. desistance) opisuje se kao vrlo zahtjevan, dinamičan i složen proces, individualno različit za svakog počinitelja kaznenog djela (Kazemian, 2007, prema McAlinden, 2016; McNeill, 2006). Stoga se na europskom području upozorava na važnost rehabilitacijskog pristupa u postupanju s počiniteljima kaznenih djela u smjeru njihove socijalne reintegracije, a u tom se smislu naglašava i značaj međuagencijskog pristupa i rada (Berry i sur., 2011; Bonta i Andrews, 2012). Ističe se da partnerski rad između agencija postaje sve važnijom značajkom u načinima na koje se nastoji utjecati na kriminalitet, pri čemu se polazi od postavke da se jedna služba ne može sama nositi ni biti odgovorna za tako složenu problematiku kao što su kriminalitet i sigurnost zajednice (Berry i sur., 2011). U tom kontekstu naglašava se i značaj suradnje zatvorskog i probacijskog sustava (Mawby i Worrall, 2011; Centre for Social Justice, 2017).

Načini na koje funkcioniraju ovi sustavi vrlo su različiti u europskim državama, a različiti su i unutar nekih europskih saveznih država, primjerice u Njemačkoj (Tabar, Miravalle, Ronco i Torrente, 2016). Dio su iste organizacijske jedinice u Engleskoj, Francuskoj i Portugalu dok su administrativno odvojeni u Grčkoj, Španjolskoj, Sjevernoj Irskoj, Škotskoj, Poljskoj i Latviji. U Norveškoj se korekcijska služba (engl. Norwegian Correctional Service) sastoji od zatvorske i probacijske službe, dakle sustavi su dio iste organizacijske jedinice, ali funkcioniraju odvojeno (Iversen, Helleso-Knusten, Stendhal i Helgesen, 2012). U Irskoj su ovi sustavi također dvije agencije u okviru iste organizacijske jedinice (engl. Department of Justice and Equality), kao što je to do sada bilo i u Hrvatskoj (McNally i Brennan, 2015). lako je u nekim zemljama spajanje sustava (2004. godine u Engleskoj, 2012. godine u Portugalu) pridonijelo većoj suradnji, donijelo je i niz novih izazova, od kojih su moguće najznačajniji (6, Bellamy, Raab, Warren, Heeney, 2007; Nash i Walker, 2009; Berry i sur., 2011; Mawby i Worral, 2011; Tabar i sur., 2016 ):

1. pitanje dijeljenja informacija

2. djelomice konfliktni ciljevi 
3. različiti načini rada

4. različit naglasak na kontroli

5. različiti mentaliteti službenika

6. poteškoće/nelagode probacijskih službenika vezane uz rad u zatvorskom okruženju.

U obavljanju svojih poslova probacijske su službe oduvijek bile usmjerenije na rad u zajednici dok su zatvorski sustavi dominantno bili usmjereni na rad unutar zatvora i kaznionica, neovisno o tome jesu li sustavi funkcionirali u okviru iste organizacijske jedinice ili odvojeno. Moguće da je to i glavni razlog zbog čega se i u državama s daleko duljom probacijskom tradicijom, kao što je to primjerice u Engleskoj i Njemačkoj, upozorava na određene poteškoće u suradnji tih dvaju sustava, ponajprije na (Maguire, 2007; Reckling, 2013; Maguire i Raynor, 2016):

1. oskudnu komunikaciju zatvorskog i probacijskog sustava

2. manjak kontinuiteta između zatvorske kazne, uvjetnog otpusta i postpenalnog prihvata

3. značajan broj recidivista u činjenju kaznenih djela i povratnika na izvršavanje kazne zatvora.

Velika zatvorska populacija još uvijek je problem u pojedinim europskim zemljama pa čak i u nekima s velikim brojem probacijskih predmeta. Jedan od načina na koji se nastoji smanjiti broj zatvorenika je i uvođenje elektroničkog nadzora, koji se primjenjuje u Engleskoj, Francuskoj, Španjolskoj, Italiji, Latviji, Portugalu, Švedskoj, Švicarskoj, Belgiji i još nekim državama. Za elektronički nadzor ističe se da može pridonijeti većem izricanju probacijskih mjera i sankcija, ali se upozorava i na negativna iskustva primjene ove tehnologije. Posebno se ističe stigmatizacija koja može ometati socijalnu integraciju, kao i primjena elektroničkog nadzora isključivo u svrhu smanjenja zatvorske populacije, bez ikakvih usluga/programa kojima bi se potaknula socijalna inkluzija (Tabar i sur., 2016; Špero i Rosandić, 2017).

Europska organizacija za probaciju (engl. Confederation of European Probation - CEP) i Europska organizacija za zatvorske sustave (engl. European Organisation of Prison and Correctional Services - EuroPris) u smjeru poboljšanja suradnje tih dvaju sustava 2013. godine potpisale su poseban sporazum (Confederation of European Probation, 2013). Od tada CEP i EuroPris zajedno organiziraju i sastanke eksperata i/ili radionice za određena područja na europskoj razini, vezano uz izazove s kojima se susreću i zatvorski sustav i probacijska služba (mentalno zdravlje, strani počinitelji kaznenih djela i sl.) (Confederation of European Probation, 2016; Confederation of European Probation, 2017).

Zajednički rad dvaju sustava potiče se i provodi uz manje ili veće poteškoće u većini europskih država, a realizira se različitim modalitetima, čija je učinkovitost dokazana ili se ocjenjuje obećavajućom (Home Office, 2000; Ourednickova, Stern i Doubravova, 2008; Riksrevisionen, 2009; National Audit Office, 2009; Mawby i Worrall, 2011; Canton, 2011; Rigsrevisionen, 2011; Maloić, Rajić i Mažar, 2015; Swedish National Council for Crime Prevention - Brä, 2015; Boone, van der Kooij i Rap, 2016; Councile of Europe, 2017; Irish Ministry for Justice and Equality, 2018):

— zajednički strateški planovi

— zajednički sastanci na nacionalnoj i regionalnoj/lokalnoj razini 
— zajednička suradnja obaju sustava s pružateljima različitih usluga/programa u zajednici

— posebni modeli u koje je uključena probacijska služba, policija i zatvorski sustav, a po potrebi se uključuju različiti pružatelji usluga iz zajednice ovisno o potrebama pojedinog zatvorenika

— zajednički informacijski sustavi s različitim razinama uvida, u okviru kojih su osnovne potrebne informacije svima dostupne

— korištenje istog instrumenta procjene kriminogenih potreba i rizika

— zajednički tretmanski programi koji se provode u obama sustavima

— rad probacijskih službenika u zatvorima i kaznionicama, zajedno sa zatvorskim službenicima

— zajednička suradnja vezana uz predlaganje otpusta zatvorenika

— konzultacije vezane uz predlaganje/primjenu elektroničkog nadzora uz uvjetni otpust

— zajednička neposredna priprema otpusta iz zatvora

— programi kuća na pola puta (engl. halfway housues programs)

— zajedničke edukacije službenika i zajednički centri za edukaciju.

Neki su od ovih oblika suradnje već dugo prisutni u europskim zemljama. Na primjer, probacijski službenici u Irskoj rade u zatvorima još od 60-ih godina prošlog stoljeća (McNally, 2009, prema McNally i Brennan, 2015). S druge strane, dok u nekim zemljama probacijska služba postoji već više desetljeća pa i više od stoljeća (kao što je to primjerice u Engleskoj i Nizozemskoj), hrvatska je služba ustrojena tek prije desetak godina (Maloić i Rajić, 2012). Navedeno svakako treba imati u vidu prilikom razmatranja razvoja suradnje zatvorskog i probacijskog sustava u našoj zemlji u nastavku rada.

\section{Unapređivanja suradnje probacijskog i zatvorskog sustava u Hrvatskoj}

S obzirom da su prvi probacijski uredi u Hrvatskoj otvoreni prije sedam godina, a da se probacijski poslovi tijekom izvršavanja kazne zatvora i uvjetnog otpusta obavljaju tek pet godina, razvoj međusobne suradnje novi je zajednički izazov za oba sustava.

Zajedničko funkcioniranje u okviru iste Uprave otvara niz novih mogućnosti suradnje, kao što je primjerice mogućnost zajedničkih edukacija probacijskih i zatvorskih službenika o izvršavanju kazne zatvora i obavljanju probacijskih poslova, sada u okviru zajedničkog Centra za izobrazbu. Aktualno se u suradnji Centra i predstavnika obaju sustava osmišljava i zajednički trening namijenjen novozaposlenim probacijskim i zatvorskim službenicima u budućnosti pri čemu se realizacija prvoga ovakva treninga očekuje tijekom 2019. godine. Predstavnici probacijskog i zatvorskog sustava i predstavnici nevladina sektora aktualno rade i na osmišljavanju posebnoga tretmanskog programa namijenjenoga počiniteljima kaznenih djela ovisnima o kockanju, čije se provođenje planira u obama sustavima. Određeni je broj probacijskih službenika educiran i za provođenje dvaju posebnih tretmanskih programa koji se već provode u zatvorskom sustavu (Prevencija ovisničkog recidiva treningom i osnaživanjem - PORTOs i Jačanje unutarnje snage - JUS-TSV - trening 
Snježana Maloić, Goran Brkić: Razvoj suradnje probacijskog i zatvorskog sustava...

socijalnih vještina). Ovakvim načinima zajedničkog rada, ali i uvođenjem drugih modaliteta koji će biti prikazani u radu, značajno pomaže orijentacija obaju sustava prema rehabilitacijskom pristupu u radu s počiniteljima kaznenih djela.

U svrhu razvoja novih modaliteta suradnje kontinuirano se analiziraju informacije dobivene izravno od probacijskih službenika i službenika kaznionica i zatvora te se temeljem provedenih analiza osmišljavaju i provode pilot-projekti. U nastavku rada prikazat će se nekoliko važnijih pilot-projekata, neovisno o tome jesu li provođeni samostalno ili u okviru europskih projekata te neovisno o broju dionika. Naime, odabrani su prema kriteriju dokazanog ili izvjesnog učinka na suradnju probacijskog i zatvorskog sustava u našoj zemlji. Dodatno će se kratko spomenuti i projekt uvođenja zajedničkoga zatvorskog i probacijskoga informacijskog sustava, s obzirom na niz prednosti koje donosi informacijsko povezivanje ovih dvaju sustava. Za prikaz svih projekata u ovom poglavlju korištena je projektna dokumentacija Ministarstva pravosuđa koja prati provođenje svakog projekta.

\section{Pilot-projekt Inicijalna procjena koristi rada probacijskog službenika u zatvoru}

Pilot-projekt Inicijalna procjena koristi rada probacijskog službenika u zatvoru provođen je od 2014. do 2017. godine u suradnji Središnjeg ureda Sektora za probaciju Uprave za kazneno pravo i probaciju i Središnjeg ureda Uprave za zatvorski sustav.

Od početka obavljanja probacijskih poslova tijekom izvršavanja zatvorske kazne, probacijski su službenici upozoravali na određene poteškoće prilikom izrade izvješća na zahtjev sudca izvršenja kod odlučivanja o prekidu zatvorske kazne i uvjetnog otpusta. Analizom je utvrđeno da službenici, u trenutku zaprimanja zahtjeva sudca izvršenja, ne raspolažu uvijek informacijama koje su im nužne za utvrđivanje/provjeru određenih činjenica u zajednici. Najlakšim i najbržim načinom prikupljanja ovih informacija činio se razgovor sa zatvorenikom. Međutim, prema zakonskim propisima koji su tada bili na snazi, nije bila jasno propisana mogućnost rada probacijskih službenika u zatvorima i kaznionicama. Dodatno, činilo se važnim i u praksi isprobati moguće načine dogovora i realizacije rada probacijskih službenika u zatvorima i kaznionicama da bi se utvrdio najjednostavniji i najbrži način realizacije. U suradnji Središnjih ureda obaju sustava tada je dogovoreno provođenje pilot-projekta s dvama ciljevima:

1. inicijalno provjeriti korist rada probacijskih službenika u zatvoru u našoj zemlji

2. utvrditi najjednostavniji način dogovora i realizacije rada probacijskog službenika sa zatvorenikom u zatvoru odnosno kaznionici.

U počeku su pilot-projekt provodili Probacijski ured Osijek i Zatvor u Osijeku da bi potom nakon pozitivnih iskustava i rezultata bili uključeni i Probacijski ured u Varaždinu, Zatvor u Varaždinu i Kaznionica u Lepoglavi.

Rad probacijskih službenika u zatvorima i kaznionici pokazao se korisnim pri izradbi izvješća za sudca izvršenja. Dodatno se pokazao korisnim i prilikom izrade izvješća na zahtjev državnog odvjetnika i suda, u postupku donošenja prijedloga ili odluke o vrsti kaznenopravne sankcije. Naime, da bi se udovoljilo ovim zahtjevima, bio je nužan razgovor probacijskog službenika s istražnim 
zatvorenikom / zatvorenikom, uz primjenu instrumenta procjene rizika i vjerojatnosti ponovna počinjenja kaznenog djela. Potreba za razgovorom probacijskog službenika sa zatvorenikom ukazivala se i u okviru pripreme zatvorenika za uvjetni otpust, primjerice u zatvorenika kod kojih su bile izvjesne poteškoće u suradnji s probacijskom službom i u okviru reintegracije u zajednicu (u pravilu se radilo o zatvorenicima s psihijatrijskim dijagnozama).

Od 2017. godine probacijski službenici svih ureda mogu realizirati rad sa zatvorenicima u svim kaznionicama i zatvorima uz vrlo jednostavne procedure dogovora i realizacije. Tomu je, osim provedenog pilot-projekta, dodatno pridonijela činjenica da sada oba sustava ustrojstveno funkcioniraju u okviru iste uprave unutar Ministarstva pravosuđa. Novim Zakonom o probaciji (Narodne novine, 99/18), koji je stupio na snagu u studenome 2018. godine, sada je člankom 3. stavkom 2. i zakonskom odredbom predviđen rad probacijskih službenika u kaznionicama i zatvorima. U bližoj budućnosti očekuje se izrada i donošenje novog Zakona o izvršavanju kazne zatvora pri čemu bi se novim odredbama, također, moglo dodatno olakšati i ubrzati suradnju.

\section{Pilot-projekt Inicijalna primjena elektroničkog nadzora u Republici Hrvatskoj}

Ovaj je pilot-projekt djelomice već prikazan u okviru domaće stručne literature (Špero i Rosandić, 2017), no ovdje se prikazuje u prvom redu sa stajališta suradnje zatvorskog i probacijskog sustava.

Pilot-projekt provodio se na području Grada Zagreba i Zagrebačke županije. Provodili su ga službenici Središnjeg ureda zatvorskog i probacijskog sustava, Probacijski uredi Zagreb I i Zagreb II, službenici zatvorskog sustava, Županijski sud u Zagrebu i Županijski sud u Velikoj Gorici te Državno odvjetništvo. Primjena elektroničkog nadzora u okviru pilot-projekta trajala je od 17. veljače do 28. svibnja 2017. godine, a nadzirana su četiri počinitelja kaznenih djela na uvjetnom otpustu i jedan u istražnom zatvoru u domu. Službenici zatvorskog sustava su u okviru pilot-projekta sudjelovali predlaganjem zatvorenika za uvjetni otpust uz elektronički nadzor, kao i pripremom zatvorenika za ovakav oblik uvjetnog otpusta. Elektroničku su opremu u domu osuđenika / istražnog zatvorenika instalirali probacijski službenici koji su 24 sata radili u nadzornom centru. Probacijska je služba s osuđenicima na uvjetnom otpustu uz elektronički nadzor, osim poslova vezanih uz sam elektronički nadzor, realizirala i sve druge sadržaje, kao i s osuđenicima na uvjetnom otpustu kod kojih nije primijenjen elektronički nadzor (procjena kriminogenih rizika i potreba, izrada individualnog programa, individualni rad s osuđenikom, suradnja s obitelji i pružateljima usluga u zajednici koji mogu pomoći vezano uz kriminogene potrebe osuđenika i smanjenje vjerojatnosti ponovnoga počinjenja kaznenog djela). Potrebe osuđenika / istražnih zatvorenika za liječničkom pomoći i sličnim realizirale su se u pratnji policije, a bilo je predviđeno i da, u vremenu kada je osuđenik trebao biti pod nadzorom, zbog eventualnog kršenja reagira policija (na primjer, nedopušteno udaljavanje iz doma).

U okviru pilot-projekta ostvarena je željena suradnja probacijske službe, zatvorskog sustava, policije, državnog odvjetništva i sudaca, dok većih problema u ponašanju počinitelja kaznenih djela koji su bili pod elektroničkim nadzorom nije bilo (te nije bilo ni potrebe za intervencijom policije zbog nedopuštena udaljavanja). Svi suradnici u okviru pilot-projekta bili su suglasni da bi elektronički nadzor trebalo trajno implementirati u našoj zemlji. Model elektroničkog nadzora korišten u 
Snježana Maloić, Goran Brkić: Razvoj suradnje probacijskog i zatvorskog sustava...

pilot-projektu (u kojem probacijska služba nadzire, a policija intervenira zbog kršenja) prihvaćen je kao vrlo realan model koji bi lako mogao biti trajno provediv u našoj zemlji. Pritom se upozorilo na potrebu izmjena zakonske regulative u budućnosti da bi se omogućila šira primjena elektroničkog nadzora (u svrhu ostvarivanja mogućnosti za ranije otpuštanje zatvorenika s izdržavanja kazne zatvora ili za zamjenu kratkih kazni zatvora). Također, naglašeno je da je elektronički nadzor nužno provoditi uz rad probacijske službe da bi se osigurao rehabilitacijski sadržaj i učinak.

U okviru projekta Jačanje kapaciteta probacijske službe sa svrhom postizanja više razine zaštite ljudskih prava i sigurnosti zajednice, koji je predložio Sektor za probaciju uz financiranje iz sredstava Norveškog instrumenta bilateralne pomoći, planira se poduzimanje predradnji potrebnih za trajno uvođenje elektroničkog nadzora, kao što su: (1) izrada zakonskih i podzakonskih akata kojima bi se reguliralo postupanje svih dionika u procesu elektroničkog nadzora, (2) ustrojavanje Nadzornog centra i nabava opreme i (3) zapošljavanje novih službenika (Ministarstvo pravosuđa, 2018b).

Uvođenje elektroničkog nadzora bilo bi korisno i za zatvorski i za probacijski sustav jer bi se na taj način mogao ranije otpustiti veći broj zatvorenika, koji bi se uz primjenu ove tehnologije postupno uključivali u zajednicu, uz smanjen rizik ponovnoga počinjenja kaznenog djela. Primjena elektroničkog nadzora uključivala bi potrebu intenzivne suradnje dvaju sustava, u dijelu pripreme zatvorenika, potom vezano uz nastavak svih tretmanskih procesa u zajednici započetih tijekom izvršavanja zatvorske kazne, kao i u slučaju eventualnog opoziva ovakvog modela uvjetnog otpusta.

\section{Pilot-projekt Priprema zatvorenika za uvjetni otpust u suradnji zatvorskog sustava i probacijske službe}

Pilot-projekt Priprema zatvorenika za uvjetni otpust u suradnji zatvorskog sustava i probacijske službe osmišljen je 2017. godine, a u provedbi je od svibnja 2018. godine. Naime, već tijekom provođenja ranije opisanoga pilot-projekta Inicijalna procjena koristi rada probacijskog službenika u zatvoru, povratnim informacijama zatvorskih i probacijskih službenika uočena je potreba dodatne pripreme zatvorenika za uvjetni otpust, u prvom redu vezanim uz njihova očekivanja, obveze i suradnju s probacijskom službom nakon otpusta. Stoga je kao glavna aktivnost ovog pilot-projekta osmišljena skupna priprema zatvorenika za uvjetni otpust, u suvoditeljstvu jednog zatvorskog i jednog probacijskog službenika. Uz tu, pilotiraju se i sljedeće aktivnosti: (1) zajednički sastanci službenika probacije i zatvorskog sustava o pojedinim rizičnijim zatvorenicima, naročito vezano uz uvjetni otpust, (2) međusobna edukacija zatvorskih i probacijskih službenika o specifičnostima rada u okviru pojedinog sustava, (3) praćenje učinaka posebnih programa na zatvorenike nakon odobravanja uvjetnog otpusta i (4) slanje zaključnog izvješća zatvorskom sustavu ili eventualno izvješća o nepridržavanju pojedinačnog programa kod nadzora uvjetnog otpusta.

Pilot-projekt se od ove godine provodi u Probacijskom uredu Zagreb I i u Zatvoru u Zagrebu. U svibnju 2018. godine realizirana je prva skupna priprema zatvorenika za uvjetni otpust u suvoditeljstvu službenika Odjela tretmana Zatvora u Zagrebu i službenika probacije. Suvoditelji opisuju adekvatan interes zatvorenika i procjenjuju ovakav oblik rada korisnim te će se nastaviti s pilotiranjem ove aktivnosti. Aktualno je u tijeku međusobna edukacija probacijskih i zatvorskih službenika pri čemu prve povratne informacije govore u prilog višestrukih koristi ovakvih edukacija i za službenike Odjela tretmana Zatvora u Zagrebu i za probacijske službenike Probacijskog ureda u Zagrebu I. 
Nadalje, osmišljen je upitnik za praćenje učinaka posebnih tretmanskih programa za zatvorenike nakon odobravanja uvjetnog otpusta, a započelo se i s primjenom upitnika u Probacijskom uredu Zagreb I. Ovaj Ured ujedno u okviru pilot-projekta sada Zatvoru dostavlja i zaključna izvješća o tijeku uvjetnog otpusta ili izvješća o nepridržavanju pojedinačnog programa.

Nakon godine dana provođenja pilot-projekta planira se provođenje pilot-projekta u još jednom probacijskom uredu i jednoj kaznionici (s obzirom na specifičnosti kaznionica u odnosu na zatvore), a potom se, u očekivanju pozitivnih rezultata, planira primjena i na razini obaju sustava u cijeloj državi.

Kao glavni doprinosi ovog pilot-projekta očekuju se učinkovitija izvršavanja zatvorske kazne i sveobuhvatnija priprema zatvorenika za uvjetni otpust, kao i svrsishodniji rad probacijske službe tijekom uvjetnog otpusta u smjeru socijalne reintegracije otpuštenog zatvorenika.

\section{Pilot-projekt Poslijepenalna zaštita - zaštita zatvorenika i zajednice}

Tijekom nadzora uvjetnog otpusta probacijska služba kod određenog broja otpuštenih zatvorenika nailazi na poteškoće iz domene poslijepenalnog prihvata/pomoći zatvoreniku, a dijelom i vezano uz potrebu zaštite zajednice. U okviru pripreme poslijepenalnog prihvata zatvorenika na probleme nailazi i zatvorski sustav. Nadalje, uočeno je da službenici sustava koji bi trebali biti nositelji poslijepenalne zaštite - zatvorski sustav, centri za socijalnu skrb, probacijska služba, policija - ne znaju dovoljno o ovlastima, mogućnostima i poteškoćama drugih sustava. Također, ne postoji sustavnije praćenje potreba zatvorenika u okviru zatvorskog sustava vezanih uz poslijepenalni prihvat ni kasnijih potreba zatvorenika tijekom reintegracije u zajednicu. Nema ni sustavnijeg praćenja o tome s kojim se sve izazovima susreću službe koje pokušavaju odgovoriti na kriminogene potrebe zatvorenika i/ili zaštititi zajednicu, s obzirom na rizike počinitelja da ponovno počini kazneno djelo i potrebu zaštite poznatih i potencijalnih žrtava i zajednice.

S obzirom na sve navedeno, u suradnji probacijskog i zatvorskog sustava osmišljen je pilot-projekt pod nazivom „Poslijepenalna zaštita - zaštita zatvorenika i zajednice” sa sljedećim ciljevima:

1. bolja međusobna informiranost institucija o radu drugih institucija

2. stjecanje sveobuhvatnijeg uvida u potrebe zatvorenika tijekom izvršavanja zatvorske kazne, uvjetnog otpusta i nakon punog isteka zatvorske kazne

3. unapređivanje zajedničke suradnje institucija na području poslijepenalne zaštite

4. unapređivanje poslijepenalne zaštite.

Provođenje pilot-projekta predviđa obuhvat zatvorenika koji će se na uvjetni otpust ili nakon isteka zatvorske kazne otpuštati na područje Grada Zagreba. Nositelj pilot-projekta je Uprava za zatvorski sustav i probaciju, a provodit će ga svi zatvori i kaznionice, Probacijski ured Zagreb I, Centar za socijalnu skrb Zagreb, Policijska uprava Zagrebačka, Centar za izvršavanje kazni zatvora Županijskog suda u Zagrebu i Županijski sud u Velikoj Gorici. Kao suradnici predviđeni su Edukacijsko-rehabilitacijski fakultet Sveučilišta u Zagrebu, Služba za podršku žrtvama i svjedocima, Hrvatski zavod za zapošljavanje, Služba za mentalno zdravlje i prevenciju ovisnosti Zavoda za javno zdravstvo "Dr. Andrija Štampar" u Zagrebu, uz širenje kruga suradnika prema iskazanoj potrebi. 
Snježana Maloić, Goran Brkić: Razvoj suradnje probacijskog i zatvorskog sustava...

Na ovaj način probacijski i zatvorski sustav teže modelima koji se već primjenjuju primjerice u Engleskoj i Irskoj. Unatoč poteškoćama u realizaciji, ti modeli svakako pridonose uključenosti i kvaliteti suradnje svih potrebnih dionika u pripremi otpusta zatvorenika i njihovoj socijalnoj integraciji. Prvi sastanak predstavnika zatvorskog i probacijskog sustava u smjeru osmišljavanja pilot-projekta održan je u svibnju 2018. godine. Prvi sastanak s potencijalnim provoditeljima održan je u listopadu 2018. godine i svi su provoditelji iskazali spremnost za sudjelovanjem, čime su se ostvarili nužni preduvjeti za početak pilot-projekta, koji se od tada i provodi.

\section{Projekt izrade zajedničkog zatvorskog i probacijskog informacijskog sustava - ZPIS}

Za što učinkovitije ostvarivanje svrhe izvršavanja zatvorske kazne, kao i za učinkovito obavljanje probacijskih poslova, potrebna je brza i ažurna razmjena informacija između zatvorskog i probacijskog sustava. Potrebne informacije o osuđeniku/zatvoreniku probacijski i zatvorski službenici sada razmjenjuju putem dopisa, elektroničke pošte ili telefonom, dakle načinima koji iziskuju vrijeme i strpljenje, pri čemu se ponekad gubi i na ažurnosti informacije, kao i na pravovremenom postupanju prema osuđeniku/zatvoreniku ili prema sudu. Na primjer, u situaciji kada se osuđenik ne javi na poziv probacijskog ureda radi izvršavanja rada za opće dobro ili kada se prestane javljati u ured, probacijski se službenik pisanim putem obraća zatvorskom sustavu da bi utvrdio da se osuđenik možda ne nalazi u zatvoru, ili u istražnom zatvoru.

U okviru proširenog projekta IPA 2012 Razvoj jedinstvenog IT sustava za zatvorsku administraciju sada se razvija Zatvorski i probacijski informacijski sustav (ZPIS), kojim će biti povezana tri sustava: zatvorski, probacijski, a kasnije i sustav podrške žrtvama i svjedocima. Inicijalna implementacija planira se od siječnja 2019. godine.

Zajednički informacijski sustav u velikoj će mjeri ubrzati razmjenu informacija između probacijskog i zatvorskog sustava. U sustavu će biti vidljive potrebne informacije o počinitelju kaznenog djela i probacijskim i zatvorskim službenicima, neovisno o tome u okviru kojeg sustava su podatci o počinitelju inicijalno ili kasnije unošeni. Na ovaj će način informacije o osuđeniku/zatvoreniku biti trenutno dostupne, čime će se omogućiti i brže postupanje zatvorskih i probacijskih službenika. Dodatno, u okviru ovog informacijskog sustava bit će ubrzani i nužni administrativni procesi jer će se primjerice za izlazne dokumente implementirati elektronički potpis, a za ulazne dokumente će se omogućiti skeniranje dokumenata.

Uvođenje zajedničkog informacijskog sustava svakako je na tragu preporučenih europskih praksi i u okviru preporuka kojima se naglašava važnost pravodobne i kvalitetne razmjene informacija između ovih dvaju sustava. 


\section{Zaključak}

Temeljem provedene analize aktualnih aktivnosti probacijskog i zatvorskog sustava u smjeru razvoja zajedničke suradnje, može se konstatirati da je i u probacijskom i u zatvorskom sustavu prepoznata potreba kontinuirana razvijanja suradnje, kao i potencijalnih koristi te suradnje za učinkovito izvršavanje zatvorske kazne i obavljanje probacijskih poslova.

Prije svega, nastoji se ostvariti što brža i kvalitetnija razmjena informacija o počiniteljima kaznenih djela, a čemu će svakako pridonijeti zajednički informacijski sustav. Zajedničkom upravom donekle su pojednostavljene i administrativne procedure dogovora zajedničkih aktivnosti. Rad probacijskih službenika u zatvorima i kaznionicama sada je moguće realizirati u okviru jednostavnih i izravnih dogovora probacijskih i zatvorskih službenika. Postignuto otvara i mogućnost širenja opsega suradnje ovih dvaju sustava novim modalitetima zajedničkog rada. Prva pozitivna iskustva suradnje imaju ohrabrujući učinak u smislu uključivanja i drugih subjekata u zajedničku inicijativu obaju sustava. U okviru pilot-projekta usmjerenog na unapređivanje poslijepenalne zaštite, teži se zajedničkom uključivanju centara za socijalnu skrb, policije, sudaca izvršenja, akademske zajednice, službe za podršku žrtvama i svjedocima i svih drugih pružatelja usluga u zajednici koji mogu pridonijeti resocijalizaciji i reintegraciji počinitelja kaznenih djela. Dakle, postoji inicijativa i težnja razvoju šire međuagencijske suradnje koja se ocjenjuje nužnom u odgovoru zajednice na kriminogene potrebe zatvorenika u smjeru smanjenja vjerojatnosti povratništva.

Može se zaključiti da se razvoj suradnje dvaju sustava usmjerava temeljem postojećih europskih iskustava. Suradnja se razvija u smjeru modaliteta koji su se u okviru europskih iskustava pokazali učinkovitima ili obećavajućima, kao što su: (1) rad probacijskih službenika u zatvorima i kaznionicama i zajedno sa zatvorskim službenicima, (2) zajednički posebni tretmanski programi koji se provode u obama sustavima, (3) zajednička neposredna priprema zatvorenika za otpust iz zatvora, (4) zajednički informacijski sustavi s različitim razinama uvida i (5) zajedničke edukacije službenika.

Jasno je da će biti potrebno još dosta vremena i rada da aktivnosti koje se sada provode u okviru pilot-projekata postanu i općeprihvaćena i ustaljena svakodnevna praksa. Prikupljanje povratnih informacija "s terena" i pilotiranje određenih aktivnosti, a prije sveobuhvatne primjene, čini se mudrim načinom uvođenja pojedinih modaliteta suradnje, s obzirom na kulturološke, ekonomske, zakonodavne i druge razlike naše zemlje i zemalja u kojima se pojedini modalitet suradnje primjenjuje. Činjenica da se od početka nastoje izbjeći/prevladati poteškoće prepoznate u suradnji europskih probacijskih i zatvorskih sustava, kao što su nedostatna komunikacija i manjak kontinuiteta rada s počiniteljem kaznenog djela, može se ocijeniti obećavajućom, naročito s obzirom na vidljive napore koji se ulažu u ostvarivanje što bolje komunikacije između dvaju sustava. Dodatno bi trebalo uložiti napore u uspostavljanje kontinuiteta rada s počiniteljem kaznenog djela, možda za početak uz primjenu istog instrumenta procjene kriminogenih potreba i rizika, primjenom kojeg bi se moglo pratiti počinitelja kaznenog djela i probacijskim i zatvorskim sustavom i temeljem kojeg bi oba sustava radila s počiniteljem. U našoj se zemlji već dugo čeka i na otvaranje prve kuće na pola puta, što bi se sada možda moglo realizirati u suradnji ovih dvaju sustava i o čemu bi svakako trebalo razmisliti. Nadalje, uvođenje elektroničkog nadzora svakako bi pridonijelo mogućnosti ranijeg uvjetnog otpusta zatvorenika i postupnom uključivanju u zajednicu. Za učinkovitu primjenu 
Snježana Maloić, Goran Brkić: Razvoj suradnje probacijskog i zatvorskog sustava...

ove tehnologije bit će potrebna dobra suradnja zatvorskog sustava i probacijske službe u pripremi takvog otpusta, kao i rad probacijske službe s otpuštenim zatvorenikom tijekom uvjetnog otpusta.

Nakon uvida u postojeći zajednički strateški dokument, a vezano uz suradnju ovih dvaju sustava, čini se potrebnim ubuduće naglasak dodatno staviti na razvoj zajedničke suradnje i zajedničkih aktivnosti. Donošenje novog Zakona o probaciji i očekivano donošenje novog Zakona o izvršavanju kazne zatvora zasigurno će dodatno olakšati i ubrzati suradnju ovih dvaju sustava.

Očekivati je da će probacijski i zatvorski sustav u našoj zemlji nastaviti rad u smjeru unapređivanja međusobne suradnje, rukovodeći se primjerima dobre prakse u europskim zemljama. Pri tome će biti potrebno međusobno uzimati u obzir specifičnosti svakog sustava, a posebno organizacijske različitosti i drukčije uvjete obavljanja poslova da bi se prevenirale i umanjile moguće poteškoće, a koje su se pojavile spajanjem ovih dvaju sustava u nekim europskim zemljama. 


\section{Literatura}

Boone, M., van der Kooij, M., Rap, S. (2016). Electronic Monitoring in the Netherlands. Universitet Utrecht. Preuzeto s: http://28uzqb445tcn4c24864ahmel.wpengine.netdna-cdn.com/ files/2016/06/ EMEU-EM-in-the-NetherlandsBriefing-report-English.pdf (29.7.2018.).

Bašić, J., Žižak, A. (1990). Relacije vrijednosti i stavova osuđenih osoba na početku penološkog tretmana. Defektologija, 26 (2), 229-241.

Berry, G., Briggs, P., Erol, R., van Staden L. (2011). A fruitful partnership - effective partnership working. London: Home Office.

Bonta, J., Andrews, D. (2012). Viewing offender assessment and rehabilitation through the lens of the risk-need-responsitivity model. U: F. McNeill, P. Raynor, C. Trotter (ur.): Offender Supervision: New directions in theory, research and practice (str. 19-38). Abingdon: Routledge.

Buđanovac, A., Mikšaj-Todorović, Lj. (2002). Stavovi prema osuđenicima i njihovoj rehabilitaciji na slovenskom i hrvatskom uzorku ispitanika. Kriminologija i socijalna integracija, 10 (2), 153-160.

Canton, R. (2011). Probation: working with offenders. Abingdon: Routledge.

Centre for Social Justice (2017). What Happened to the Rehabilitation Revolution? London: Centre for Social Justice.

Confederation of European Probation (2013). European probation and prison organisations consolidate their strategic alliance. Preuzeto s: https://www.cep-probation.org/wpcontent/ uploads/ 2015/02/CEP-Newsletter-August-201 3.pdf. (3.7.2018.).

Confederation of European Probation (2016). Workshop on Foreign National Offenders. Preuzeto s: https://www.cep-probation.org/workshop-on-foreign-national-offenders-brugge/ (3.7.2018.).

Confederation of European Probation (2017). CEP and EuroPris workshop on Mental Health in Prison and Probation. Preuzeto s: https://www.cep-probation.org/cep-europris-workshop-mental-health-prison-probation/ (13.7.2018.).

Councile of Europe (2017). Staff Recruitment, Training and Development in the $27^{\text {st }}$ Century. $22^{\text {nd }}$ Council of Europe Conference of Directors of Prison and Probation Services. Preuzeto s: $h t t p s: / /$ cdn1.fpfis.tech.ec.europa.eu/epale/cdn/farfuture/na6W3VdjgFnxaHDsn02QLvaLkSpqU5siOtVYswAFnek/mtime:1531467449/sites/epale/files/information_about_the_training_ of the_correction_staff-_vs_24.05.17.docx.pdf (14.7.2018.).

Damjanović, I., Jandrić, A. i Doležal, D. (2002). Uloga rehabilitacije u svjetlu novih promjena unutar zakona o izvršavanju kazne zatvora. Kriminologija i socijalna integracija, 10(1), 49-58.

Home Office (2000). Risk and need assessment in probation services: an evaluation. Home Office Research Study 211. Preuzeto s: http://library.college.police.uk/docs/hors/hors211.pdf (28.7.2018.).

Iversen, H.H., Helesso-Knusten, K., Stendhal, I., Helgesen, J. (2012). Changes in Norwegian probation officers> attitudes, behaviour, perceptions and evaluations following a national safety training intervention. EuroVista, 2, (2), 78-89.

Jandrić, A. (2006). Izvaninstitucionalni programi rada s ovisnicima o ilegalnim drogama: mogućnosti izricanja alternativnih sankcija punoljetnim osuđenim ovisnicima. Zbornik Pravnog fakulteta Sveučilišta u Rijeci, 27(2), 1033-1053. 
Snježana Maloić, Goran Brkić: Razvoj suradnje probacijskog i zatvorskog sustava...

Irish Ministry for Justice and Equality (2018). Joint Irish Prison Service / Probation Service Strategic Plan 2018-2020. Preuzeto s: http://www.probation.ie/EN/PB/0/BC80C26316E56DEA802582B700 3CD1AC/\$File/IPS\%20Strategic\%20Plan\%202018-2020_Final-lr.pdf (30.6.2018.).

Kazneni zakon. Narodne novine, 125/11, 144/12, 56/15, 61/15, 101/17.

Kovčo, I. (1997). Penološki institucionalni tretman počinitelja ubojstva. Kriminologija i socijalna integracija, 5(1-2), 53-66.

Kovčo, I. (2001). Kazna zatvora - zašto i kuda? Hrvatski ljetopis za kazneno pravo i praksu, 8(2), 117-136.

Kovčo Vukadin, I., Rajić, S., Maloić S. (2011). Izazovi u izgradnji probacijskog sustava u Republici Hrvatskoj. Hrvatski ljetopis za kazneno pravo i praksu, 18(2), 717-735.

Kovčo Vukadin, I., Lotar, M., Barić, M. (2012). Nasilje u hrvatskom zatvorskom sustavu: rezultati kvantitativnog istraživanja. Istraživanja u edukacijsko-rehabilitacijskim znanostima Knjiga sažetaka 8. međunarodnog znanstvenog skupa. Preuzeto s: https://www.bib. irb.hr/607942 (30.7.2018).

Kovčo Vukadin I., Špero J. (2015). Hrvatski probacijski sustav: postignuća i perspektive. Hrvatski ljetopis za kazneno pravo i praksu, 22(2), 671-715.

Maguire, M. (2007). The resettlement of ex-prisoners. U: L. Gelsthorpe, R. Morgan (ur.): Handbook of Probation (str. 398-424). Cullompton: William Publishing.

Maguire, M., Raynor, P. (2016). Offender management in and after prison: The end of 'end to end'? Criminology and Criminal Justice, 17(2), 1-20.

Maloić, S., Rajić, S. (2012). Potreba i značaj razvoja suradnje probacijskog sustava i sustava socijalne skrbi u RH. Ljetopis socijalnog rada, 19(1), 29-52.

Maloić, S., Rajić, S. i Mažar, A. (2015). Značaj suradnje probacijskog i zatvorskog sustava u prevenciji kriminalnog povrata. Kriminologija i socijalna integracija, 23(1), 129-156.

Mawby, R. C., Worrall, A. (2011). There were very threatening about do-gooding bastards": Probation's changing relationships with the police and prison services in England and Wales. European Journal of Probation, 3(3), 78-94.

McAlinden, A. (2016). The Reintegration of Sexual Offenders. Irish Probation Journal, 13, 5-21.

McNally, G., Brennan, A. (2015). Community Return: A Unique Opportunity. Irish Probation Journal, 12, 141-159.

McNeill, F. (2006). A desistance paradigm for offender management. Criminology and Criminal Justice, 6(1), 39-26.

Mejovšek, M. (1998). Kibernetički model penološkog tretmana. Hrvatska revija za rehabilitacijska istraživanja, 34(1), 31-38.

Mihoci, M. (2006). Sigurnost kaznionica i zatvora. Hrvatski ljetopis za kazneno pravo i praksu, 13(2), 879-905.

Mikšaj-Todorović, Lj., Buđanovac, A. (2000). Javno mnijenje o prijestupnicima i rehabilitaciji u Hrvatskoj: Utjecaj spola, dobi, obrazovanja i razine urbanizacije. Kriminologija i socijalna integracija, 8(1-2), 27-34.

Ministarstvo pravosuđa (2014). Izvješće o radu probacijske službe za 2012. godinu. Preuzeto s: https:// pravosudje.gov.hr/UserDocs/mages/dokumenti/probacija_2012_.pdf. (30.6.2018.) 
Ministarstvo pravosuđa (2017). Izvješće o stanju i radu kaznionica, zatvora i odgojnih zavoda za 2016. godinu. Preuzeto s: https://pravosudje.gov.hr/UserDocs/mages/dokumenti/Pravo\%20 na\% 20pristup\%20informacijama/Registri\%20i\%20baze\%20podataka/lzvjesce\%200\%20 stanju\%20i\%20radu\%20kaznionica\%20zatvora\%20i\%20odgojnih\%20zavoda\%20za\%20 2016.pdf (28.4.2018.).

Ministarstvo pravosuđa (2018a). Izvješće probacijske službe za 2017. godinu. Preuzeto s: https://www. sabor.hr/sites/default/files/uploads/sabor/2019-01-18/081548/IZVJESCE_ PROBACIJS KA-SLUZBA- 2017.pdf (25.2.2019.)

Ministarstvo pravosuđa (2018b). Strateški plan ministarstva pravosuđa za razdoblje 2019. - 2021. Preuzeto s: https://pravosudje.gov.hr/UserDocs/mages/dokumenti/Strategije,\%20planovi,\%20izvje šća/Planovi/Strateški\%20plan\%20Ministarstva\%20pravosuđa\%20za\%20 razdoblje\%202019\%20do\%202021..pdf (25.7.2018.).

Nash, M., Walker, L. (2009). Mappa - is closer collaboration really the key to effectiveness? Policing, 3(2), 172-180.

National Audit Office (2009). The National Offender Management Information System. London: The Stationery Office.

Ourednickova, L., Stern, P., Doubravova, D. (2008). The Czech Republik. U: A.M. Kalmthout, I. Durnescu (ur.): Probation in Europe. Wolf Legal Publishers/CEP. Preuzeto s: https://www. cep-probation.org/uploaded_files/Czech\%20Republic.pdf (28.7.2018.).

Peto Kujundžić, L., Vukota, Lj. (2009). Čemu nas je podučio prikaz probacijskog sustava u Engleskoj i Walesu. Hrvatski ljetopis za kazneno pravo i praksu, 16(1), 319-328.

Reckling, P. (2013): Transition and Discharge Management between Prison and Aftercare in Germany. World Congress on Probation, 8-10 October 2013. Retrieved 20 May, 2014 from http:// www.worldcongressonprobation.org/page/555/presentations (30.4.2018.).

Rigsrevisionen (2011). Extract from the report to the Public Accounts Committee on the initiatives implemented by the Danish Prison and Probation Service to reduce reoffending. Preuzeto s: http://uk.rigsrevisionen.dk/media/1885886/10-2010.pdf (29.7.2018.).

Riksrevisionen (2009). The work of the Swedish Prison and Probation Service to prevent reoffending. Preuzeto s: https://www.riksrevisionen.se/download/18.78ae827d1605526e94b32a53/151843546 4732/summary_rir_\%202009_27.pdf (28.7.2018.).

Swedish National Council for Crime Prevention - Brä (2015). Work, education and treatment in Swedish prisons. Summary of report No. 2015:20. Preuzeto s: https://www.bra.se/download/ 18.31d7fffa1504bbffea065d06/1448970661178/2015_20_Work\%2C+training+and+treatment+in+Swedish+prison_r.pdf (28.7.2018.).

Šimpraga, D., Vukota, Lj. (2010). Probni projekt Uvjetni otpust zatvorenika. Hrvatski ljetopis za kazneno pravo i praksu, 17(2), 813-817.

Špero, J., Rosandić, P. (2017). Elektronički nadzor pilot-projekt u Republici Hrvatskoj. Hrvatski ljetopis za kaznene znanosti i praksu, 24(2), 671-692.

Tabar, O.F., Miravalle, M., Ronco, D., Torrente, G. (2016). Reducing the prison population in Europe: does community justice work. Rim: Antigone Edizioni. Preuzeto s: http://www.ub.edu/ ospdh/sites/default/files/documents/epo_ws_1_final_report_reducing_the_prison_population_in_europe._does_community_justice_work.pdf (25.7.2018.).

Uzelac, S., Žakman-Ban, V., Farkaš, R. (2008). Rad zatvorenika u fazi adaptacije na zatvorske uvjete u hrvatskoj kaznionici. Kriminologija i socijalna integracija, 16 (1), 79-108. 
Snježana Maloić, Goran Brkić: Razvoj suradnje probacijskog i zatvorskog sustava...

Zakon o probaciji. Narodne novine, 153/09.

Zakon o probaciji. Narodne novine, 143/12.

Zakon o probaciji. Narodne novine, 99/18.

Zakon o izvršavanju kazne zatvora. Narodne novine, 128/99, 55/00, 59/00, 129/00, 59/01, 67/01, $11 / 02,190 / 03,76 / 07,27 / 08,83 / 09,18 / 11,48 / 11,125 / 11,56 / 13,150 / 13$.

Žakman-Ban, V. (1992). Povratništvo-uvijek aktualan krivičnopravni, kriminalnopolitički i penološki problem. Defektologija, 28(1-2), 93-11.

6, P., Bellamy, C., Raab, C., Warren, A., Heeney, C. (2007). Institutional Shaping of Interagency Working: Managing Tensions between Collaborative Working and Client Confidentiality. Journal of Public Administration Research and Theory, 17(3), 405-434. 
Snježana Maloić

Ministry of Justice

Sector for Probation

Goran Brkić

Ministry of Justice

Sector for Probation

\title{
Development of cooperation between the probation and prison system - are we heading in the right direction?
}

\begin{abstract}
The Croatian Probation Service was established in 2011. In 2013 it began with execution of probation—related tasks in terms of execution of prison sentences and conditional release. Since then, the number of such cases has continuously increased. Nowadays, they account for half of all the incoming cases on an annual basis. The increased caseload and higher involvement of the probation service during the enforcement of prison sentences and conditional releases points to the need for closer cooperation between the probation and prison services. Effective cooperation between probation and prison services is considered necessary for purposeful enforcement of prison sentences and probation tasks at the European level. Within the framework of the rehabilitative approach, certain limitations have been found in terms of the existing cooperation. At the same time, some modalities proved to be more effective or promising have been emphasized. This paper presents an analysis of the cooperation development between probation and prison services in our country compared to the current situation in Europe, with closing remarks indicating the need for further development of this cooperation whereby the best European practices should serve as a role model.
\end{abstract}

Key words: probation, probation tasks, prison, prison sentence, conditional release 